From the Field: developments in clinic around the world

\title{
The Growth of Legal Clinics in Europe - Faith and Hope, or Evidence and Hard Work?
}

Maxim Tomoszek,

Palacky University, Olomouc, Czech Republic

maxim.tomoszek@upol.cz

Clinical legal education is a quickly growing and developing concept. Even in countries with traditionally conservative approaches to legal education and within very traditional institutions, we can observe significant growth of legal clinics. Throughout the Western Europe, which was considered to be the last holdout in the worldwide acceptance of clinical legal education, ${ }^{1}$ many new legal clinics are being founded, changing the traditionally theoretical approach to legal education. Does it mean that the global environment of legal education is changing? What are the sources of this unprecedented spread of legal clinics? And what will be the consequences of this trend for legal education in a broader sense? I will endeavor to answer these questions mostly from the Czech and European perspective with a goal to bring some inspiration in a global context. In the end, I would like to share the surprising insights about clinical legal education I have gained at the conference dedicated to judicial independence and accountability.

First, I would like to make several observations. Legal clinics certainly are not a recent concept. The first clinics were established in the end of the $19^{\text {th }}$ century and

\footnotetext{
${ }^{1}$ Wilson,R., Western Europe: Last Holdout in the Worldwide Acceptance of Clinical Legal Education - Part I/II, 10 German Law Journal 823-846 (2009), available at http://www.germanlawjournal.com/index.php?pagelD=11\&artID=1123.
} 
there was a significant discussion among scholars about the necessity of this type of legal education. ${ }^{2}$ I find this very logical, since law is perfectly suited, or even requires to be taught in a practical way. The legal profession, as one of the helping professions, requires its members to master many professional skills. That is why law students quickly understand that a purely theoretical method of teaching law cannot prepare them properly for their future career in the legal profession and start looking for other sources of practical experience to compensate for that. It is remarkable that students also recognize the educational value of clinics on the area of theoretical knowledge - legal clinics allow them to acquire deeper and practical understanding of theoretical concepts, and most importantly require the students to combine and connect knowledge from different areas of law (i.e. different subjects) to get a full picture of the legal situation of the client. Thus legal clinics also offer a solution to the criticized compartmentalized nature of law studies.

Another important element often lacking in traditional legal education are professional values, again often due to theoretical nature of legal studies. A third factor important for development of legal clinics is the fact that there are many people in need of professional legal aid, who cannot afford to pay for a professional lawyer, despite the fact that states, bars or NGOs make huge efforts to make the situation better. At the same time, raising the awareness of law student to social

${ }^{2}$ Bloch, F., The Global Clinical Movement. Education Lawyers for Social Justice. Oxford: Oxford University Press, 2011, p. 5; Rekosh, E.,The Development of Clinical Legal Education: A Global Perspective - International Experience, the History of Legal Clinics. in: Łomowski, D. (ed.) The Legal Clinics. The Idea, Organization, Methodology. Warszawa: C. H. Beck, 2005, p. 45; Stilwell, P. (ed.), Clinical Law in South Africa. Lexis Nexis Butterworths 2004, p. 1; Who we are?, accessible at http://archive-dk.com/page/214151/2012-0827/http://www.retshjaelpen.dk/eng/who-we-are, accessed on 30 ${ }^{\text {th }}$ May 2014. 
justice elements of law motivates them and makes them better prepared for legal practice.

Legal clinics contribute significantly to all these areas, so it is remarkable that there were so many unsuccessful clinical projects all over the world, but especially in Europe. Therefore the question we ask should not be "Why did clinics develop now?" but rather "Why they did not last in the past?" and "Why are they rediscovered (in certain countries) exactly now?"

I would like to start answering these questions by using the example of the Czech Republic, which can be perceived as a bridge between Western and Eastern Europe and shares many common features with countries from both parts of Europe. The legal education was traditionally very theoretical, with occasional discussions about the lack of practical elements. ${ }^{3}$ In the 1990s, there were several clinical projects taking place at different law schools, but none of them was particularly successful. ${ }^{4}$ The reasons why these projects were not successful in the sense of long-term sustainability were astutely analyzed by Richard Wilson ${ }^{5}$ focusing on situation in Western European and especially Germany and Stefan Krieger analyzing the

\footnotetext{
${ }^{3}$ Bobek, M. O (ne)reformovatelnosti studia práv v Čechách. Právní rozhledy, No. 10/2005, pp. 365-370; No. 12/2005, pp. 446-451; No. 14/2005, pp. 523-529 and No. 16/2005, pp. 601-606. Bobek also cites discussions from 1927 - Pošva, K., K reformě studia právnického. Hovorna časopisu Právník, Vol. LXVI (1927), pp. 132-133, Dymeš, B., K reformě studia právnického. Hovorna časopisu Právník, Vol. LXVI (1927), pp. 196 a 197.

${ }^{4}$ A very illustrative example of such a project was the housing clinic in Olomouc - Krieger, S. H., The Stories Clinicians Tell. in: Tomoszek, M. (ed.), Complex Law Teaching: Knowledge, Skills and Values. Olomouc: Palacký University, 2013, pp. 11-36. Available at: http://www.pf.upol.cz/fileadmin/user_upload/PF/Centrum/Complex Law elektronicky- upravena.pdf, accessed on 30th May 2014.

${ }^{5}$ Wilson, 2009, p. 831-835.
} 
situation in the Czech Republic. ${ }^{6}$ The factors they identified as main obstacles to development of clinical legal education were the higher demands on methodology and organization within live-client clinics, existence of apprenticeships as a first stage of legal professions, legal obstacles such as non-existent student practice rule, the organization of legal practice and lack of social justice sensitivity at law schools. Other common obstacles perceived by starting clinicians in Europe are the fact that many law teachers are members of the bar and the bar opposes legal clinics as unfair competition due to potential low quality of advice, and criticizes clinics due to lack of insurance and confidentiality.

The story of legal clinics in Olomouc continues in 2002, when a very young Dean, Michal Malacka, decided to re-establish legal clinics at the law school. There were two main reasons to do that - one of them was the 'tradition' or rather an institutional memory of having the clinic in the 1990s. The other was the need to distinguish the relatively new law faculty in Olomouc from other, much more traditional and well-established law faculties in the Czech Republic. The clinic did not respect any basic rules of clinical legal education methodology, since it was organized and taught by the people with no experience in this area. In 2006, the law faculty in Olomouc acquired a substantial financial support from European Social Fund, ${ }^{7}$ which allowed it to train the teachers in the clinical methodology and to

\footnotetext{
${ }^{6}$ Krieger, 2013, pp. 13-15.

7 Project of HRD OP “Development of practical forms of teaching at LF PU” (reg. no. CZ.04.1.03/3.2.15.2/0273), financed from the sources of European Social Fund and state budget of the Czech Republic.
} 
develop a complex clinical programme, which is not only still operating, but steadily growing.

At first, the clinical programme in Olomouc was considered to be an experiment by other law faculties. However, after it became well established and positively appraised by students and professionals, the law faculties of Charles University in Prague and Masaryk University in Brno have realized the importance of having complex systems of practical legal education embedded within the law school curriculum, including legal clinics, and currently offer several clinical or skillsoriented courses.

Does it mean that the above-mentioned obstacles have been overcome? I have the impression that the recent intensive development of legal clinics in the Czech Republic (and also in other European countries) derives from understanding that traditional legal education was inefficient and did not focus enough on skills and professional values. The importance of skills and values as a qualification requirement for legal profession is clearly formulated in CCBE (Council of Bars and Law Societies of Europe) recommendation ${ }^{8}$ similar to ABA's so-called MacCrate report. ${ }^{9}$ The need for development of key competences during higher education is

\footnotetext{
${ }^{8}$ CCBE Recommendation on Training Outcomes for European Lawyers, accessible at http://www.ccbe.org/fileadmin/user upload/NTCdocument/EN Training Outcomes1 1196675213.pdf;

${ }^{9}$ American Bar Association, Legal Education and Professional Development - An Educational Continuum. Report of the Task Force on Law Schools and the Profession: Narrowing the Gap. Accessible at: http://www.americanbar.org/content/dam/aba/publications/misc/legal_education/2013_legal_education_and _professional_development_maccrate_report).authcheckdam.pdf
} 
expressed in the Resolution of European Parliament. ${ }^{10}$ Legal clinics were even recognized by United Nations resolution. ${ }^{11}$ These documents were undoubtedly strong enough arguments to overcome the resistance of conservative members of law academia and the voices saying that clinical legal education is too cost-inefficient. However, other obstacles were not so easy to overcome. The newly established wave of law clinics is therefore still lacking with regard to student representation in court or filling the gap in the free legal aid system. It is striking that in many European countries, the social justice element of legal clinics is often neglected and underrated, or even non-existent, due to focus on simulation clinics or diminishing the extent of help provided by clinics to people in need.

The change in overall attitude to legal education can be demonstrated on the influence of legal clinics on the law school curriculum. In Olomouc, there are many members of the faculty who combine teaching of substantive, compulsory subjects, with supervision in legal clinics. This combination allows them best to understand the problems of traditional legal education, especially when compared to legal clinics. This experience leads them to improve their teaching methodology in substantive subjects and slowly changes the overall methodology in the curriculum. Since 2006, the attitude to teaching changed significantly and lead to accreditation of

\footnotetext{
${ }^{10}$ Recommendation of a European Parliament and Council no. 2006/962/EC on key competencies for life-long learning, accessible at http://www.cmepius.si/files/cmepius/userfiles/grundtvig/gradivo/key_competencies_2006_en.pdf

${ }^{11}$ Resolution adopted by the General Assembly of the United Nations: United Nations Principles and Guidelines on Access to Legal Aid in Criminal Justice Systems. Accessible at http://www.unodc.org/documents/justice-andprison-reform/UN principles and guidlines on access to legal aid.pdf, accessed on 30th May 2014, para. 61 (a), 71 (e), 72 (a) and (b).
} 
a new curriculum in 2009, profoundly different from any previous law school curriculum in the Czech Republic.

At this point, I come to the insights I have gained at the conference on judicial independence and accountability, which took place on $31^{\text {st }}$ May and $1^{\text {st }}$ June 2014 in Brno. ${ }^{12}$ Its main focus was the administration of judiciary and especially the functioning of judicial councils in different countries. It is remarkable that they were adopted in many countries in a wave, which was argued to be caused by international pressure but also by attractiveness and fashionableness of judicial councils. Countries that resisted this trend were among others Germany and the Czech Republic. In the presentations at the conference, a research was presented concluding that judicial councils in fact do not increase judicial independence. In several countries, the judicial council had the opposite effect - some of the top officials from within the judiciary used them to control the judiciary as a whole for their own purposes.

I would like to make a parallel between the adoption of judicial councils and growth of clinical legal education in European countries. The basis for this parallel is the fact that the current developments in the area of clinical legal education can probably be also, at least partially, attributed to the fact that clinics are trendy and fashionable these days. And some countries with more conservative approach to legal education, for example Germany, also opposed this trend. The positive contribution of clinical

\footnotetext{
${ }^{12}$ You may find the detailed programme of the conference at http://jinepravo.blogspot.cz/2014/03/konference-politics-of-judicial.html
} 
legal education towards the overall outcome of legal education system still has not been proven by a rigorous empirical evidence-based study - it is mostly based on belief of clinical teachers and clinical students. ${ }^{13}$ So put in simple words - many of us very much like the idea of implementing something, lot of other people say it is great, we ourselves consider it to be great (or maybe we just feel that we should not be the only ones without it), so we do it!

I think there are two major lessons to be learnt from this parallel: first, it is important to be sure and to have evidence that clinical legal education really can achieve the goals that are usually attributed to it. Most of the clinical teachers and students are intuitively convinced that legal clinics have these effects. However, latest research shows that intuitive conclusions can be very wrong, especially when there is strong bias. ${ }^{14}$ Therefore it is of utter importance to rigorously research the outcomes of clinical legal education and present clear scientific evidence of their benefits. I am convinced that the conditions right now allow conducting such research very effectively and on global scale, making the outcomes of the research relevant and persuasive. There are several international clinical networks, which could serve as a platform for organizing and conducting such research.

The second lesson to be learnt is that when adhering to a widely spread trend and adopting some new features (judicial councils or legal clinics), it is extremely important to do it well, especially if we ourselves are convinced that these new

\footnotetext{
${ }^{13}$ For detailed analysis see Krieger, 2013, pp. 30-33.

${ }^{14}$ Kahneman, D., Thinking, Fast and Slow. Macmillan, 2011.
} 
features are really a positive development and want them to spread further. If we do not do it well and fail, we will significantly weaken the reputation of other people doing the same thing somewhere else, because we will be an example that it does not work or even works in opposite direction and that is excellent ammunition for critics and opponents. It means that becoming a member of international community of legal clinicians brings a lot of responsibility. Luckily, clinicians all over the world are in my own experience extremely forthcoming and helpful people, who gladly share their know-how and provide help to anyone in need. The exchange of information is already working on global, regional and national scale. There are several associations, which serve as platforms for such exchange, there are regular conferences taking place all over the world, and there are many supporters of idea of clinical legal education among members of legal professions, NGOs, international organizations, or human rights activists.

Going back to the questions from the beginning of this text, I would like to conclude that the environment of clinical legal education has definitely changed a lot. It is currently very open to innovations improving its results in the area of skills development and professional values. Legal clinics are widely accepted as a very effective mean to achieve that. The sources of this change were the recognition of importance of practical methods of teaching on many different levels and in many different contexts. What does all this mean for the future development in clinical legal education? 
All these factors significantly increase the importance of networking. There are several excellent examples of benefits of establishing a clinical network, be it on national level (CLEO in UK, CLEA in USA or FUPP in Poland) or globally (GAJE). Several new networks are being established right now or have been established recently (European Network for Clinical Legal Education, Francophone network on clinical legal education, Jordanian Association for Legal Clinics). This all leads to unprecedented global communication and exchange of information. It also means that clinics are not experiment involving a couple of (hundreds of) people anymore clinical legal education is a massive and global phenomenon. However, the global clinical community should not get too comfortable and rest. There are certainly countries of regions (including Europe), which still need significant help to make legal clinics a standard part of legal education.

However, in my understanding, clinical legal education is not a goal in itself; it is just one of the steps on the road to achieve truly important goals on global scale, most importantly reforming legal education and achieving social justice for everyone. I think that now the focus within clinical legal education will shift from expansion to quality and effectively achieving these goals, (re-)opening questions such as "How can we improve non-clinical legal education by our clinical experience?" and "How can legal clinics have greater social impact?" 